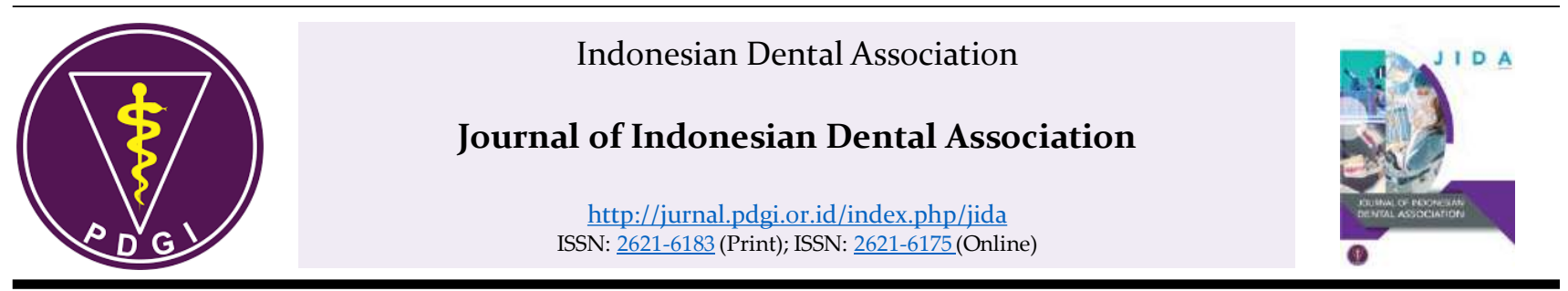

Research Article

\title{
Mahkota Dewa (God's Crown) Fruit Extract Inhibits the Formation of Periodontal Pathogen Biofilms in vitro
}

\author{
Diajeng Celia Radita ${ }^{1}$, Armelia Sari Widyarman ${ }^{2 \S}$ \\ ${ }^{1}$ Undergraduate Student, Faculty of Dentistry, Trisakti University, Indonesia \\ ${ }^{2}$ Department of Microbiology, Faculty of Dentistry, Trisakti University, Indonesia
}

Received date: June 12, 2019. Accepted date: October 4, 2019. Published date: October 31, 2019

\section{KEYWORDS \\ Aggregatibacter \\ actinomycetemcomitans; \\ biofilm; \\ mahkota dewa fruit; \\ Porphyromonas gingivalis; \\ Treponema denticola}

\begin{abstract}
Introduction: Mahkota dewa (Phaleria macrocarpa) is an Indonesian fruit that contains antibacterial compounds, such as flavonoids, saponins, and tannins; it has been used as an alternative treatment for controlling infection. Objectives: This study aimed to examine the effect of mahkota dewa fruit extract on the formation of Porphyromonas gingivalis ( $P$. gingivalis), Aggregatibacter actinomycetemcomitans (A. actinomycetemcomitans), and Treponema denticola ( $T$. denticola) biofilms in vitro. Methods: God's crown fruit was extracted using the maceration technique, and then diluted into different concentrations $(25 \%$, $12.5 \%, 6.25 \%, 3.125 \%$, and $1.56 \%$ ) using phosphate buffered saline (PBS). P. gingivalis ATCC-33277, A. actinomycetemcomitans ATCC-29522, or T. denticola ATCC-35405 were cultured in brain heart infusion (BHI) broth, 24h (anaerobic-condition), and then each type of bacteria $\left(10^{8} \mathrm{CFU} / \mathrm{mL}\right)$ was distributed into a 96-well microplate to form a biofilm. Subsequently, the fruit extracts were distributed into the biofilm-containing well plates and incubated for $1 \mathrm{~h}, 6 \mathrm{~h}$, and $24 \mathrm{~h}$. A biofilm without the fruit extract and chlorhexidine-gluconate $(0.2 \%)$ was used as the negative and positive control, respectively. Crystal violet $(0.5 \% \mathrm{w} / \mathrm{v})$ was used to determine the density of the remaining biofilm using a microplate spectrophotometer $(600 \mathrm{~nm})$. Data were statistically analyzed using one-way ANOVA, and $p<0.05$ was set as the level of significance. Results: The mahkota dewa fruit extracts significantly inhibited the formation of a biofilm for all three bacterial strains at all concentrations and for each incubation time $(p<0.05)$ based on optical density (OD) \pm SD. The best concentration of fruit extract to inhibit biofilm formation was $25 \%$ for $P$. gingivalis (OD=0.19 \pm 0.06$), 12.5 \%$ for $A$. actinomycetemcomitans $(\mathrm{OD}=0.14 \pm 0.16)$, and $25 \%$ for $T$. denticola $(\mathrm{OD}=1.17 \pm 0.19)$ in comparison to the biofilm mass of the negative control, which was $1.67 \pm 0.06,1.17 \pm 0.34$, $2.66 \pm 0.38$ for $P$. gingivalis, A. actinomycetemcomitans, and $T$. denticola, respectively. Conclusion: Based on these results, mahkota dewa fruit extract can inhibit the formation of biofilm on $P$. gingivalis, A. actinomycetemcomitans, and $T$. denticola, and it may potentially be used to prevent the infection associated with periodontal disease.
\end{abstract}

${ }^{\S}$ Corresponding Author

E-mail address: armeliasari@trisakti.ac.id (Widyarman AS)

DOI: $10.32793 /$ jida.v2i2.404

Copyright: (02019 Radita DC, Widyarman AS. This is an open access article distributed under the terms of the Creative Commons Attribution License, which permits unrestricted use, distribution, and reproduction in any medium provided the original author and sources are credited. 


\section{INTRODUCTION}

Oral and dental disease, especially periodontal disease, is one of the main diseases around the world. ${ }^{1}$ According to Basic Health Research (RISKESDAS), in 2003 , the percentage of people with oral and dental disease increased from $23.2 \%$ to $25.9 \%$, and the prevalence of periodontal disease is $96.58 \% .^{2}$ Periodontal disease is defined as an inflammation in the gingival tissue, periodontal ligament, and bone structure which support teeth. ${ }^{3}$ The main etiology of periodontal disease is dental biofilm and bacterial plaque. ${ }^{4}$ Porphyromonas gingivalis ( $P$. gingivalis), Treponema denticola ( $T$. denticola), Tannerella forsynthensis, Aggregatibacter actinomycetemcomitans (A. actinomycetemcomitans), Fusobacterium nucleatum, Eikenella corrodens, and Prevotella intermedia are the types of bacteria involved in periodontal disease. ${ }^{5}$

$P$. gingivalis and $T$. denticola are Gram-negative bacteria in the oral cavity that are involved in the pathogenesis of periodontal disease, especially chronic periodontitis. The bacteria destroy the periodontal ligament, leading to tooth loss. A. actinomycetemcomitans is a Gram-negative anaerobic bacteria involved in the pathogenesis of aggressive periodontitis. ${ }^{6}$ Accumulated bacteria build a biofilm in the oral cavity, leading to inflammation in the periodontal tissue. ${ }^{7} \mathrm{~A}$ biofilm is defined as a microorganism aggregation that adheres to the surface of teeth and is enclosed in extracellular polymeric substances (EPS) ${ }^{8}$ While biofilm is irremovable, the pathogenesis of dental biofilm plaque can be reduced in the oral cavity by balancing normal oral flora with oral hygiene procedures, such as tooth brushing, flossing, and rinsing with antimicrobial mouthwash. ${ }^{7}$

Bacterial growth and the pathogenesis of periodontal disease can be overcome using various therapies, including non-surgical procedures, such as scaling and root planning, and surgical procedures alongside antibiotic therapy. Tetracycline, clindamycin, penicillin, metronidazole, macrolides, minocycline, chlorhexidine, and doxycycline are the most commonly used antibiotics, systemically or locally. Research has shown that the increasing prevalence of periodontal disease makes this disease difficult to overcome, even with the therapies mentioned above. ${ }^{5}$ The side effect of antibiotic therapy can cause pathogens to have antibiotic resistance.

Since ancient times, people have been using natural products to treat various diseases due to their potentials of bioactivity, that can lead to drug discovery and development. ${ }^{9}$ The pharmaceutical industry has begun to take an interest in herbal plants that have antibacterial, antioxidant, and anti-inflammation properties. ${ }^{10}$ The increasing incidence of disease around the world, pathogenic bacterial resistance against antibiotics, and increasing healthcare costs in developing countries are factors that support the use of herbal plants. ${ }^{1}$ Therefore, a new exploration of herbal plants is needed. ${ }^{11}$ God's Crown (mahkota dewa) is a native Indonesian plant that has the potential as an alternative to treat some dieases. ${ }^{12}$

God's Crown (Phaleria macrocarpa) originated from Papua in Indonesia, and it grows in the tropics. ${ }^{11}$ Traditionally, this fruit has been found to have clinical advantages, and it is usually used to treat cancer, impotence, hemorrhoids, diabetes mellitus, allergies, hepar diseases, heart disease, kidney disease, blood disorders, stroke, itchiness, and some skin diseases. ${ }^{12}$ Research has demonstrated that flavonoid, the largest component in God's Crown extract, can inhibit Grampositive and Gram-negative bacteria. ${ }^{11,13}$ Secondary metabolite components of this plant, such as saponin, tannin, alkaloid, terpenoids, falerin, mangiferin, and gallic acid, have been tested in vitro; they have shown antitumor, anti-hyperglycemic, anti-hyperlipidemic, antiinflammation, anti-diarrheal, vasodilator, antioxidant, anti-viral, antibacterial, and anti-fungal properties, and, when taken as a dietary supplement, God's Crown has been found to increase fertility in males. ${ }^{14-16}$

In dentistry, many research have been conducted to find potential alternative treatments from natural products against oral diseases. For example, it has been reported that bromelain, an enzyme isolated from Indonesia's pineapple hump, was effective against the growth of endodontic pathogen E. faecalis in vitro. ${ }^{17}$ Other fruits, such as strawberry, in the form of crude extracts also have antibacterial activity against several oral pathogens in vitro, including $E$. faecalis and $P$. gingivalis. ${ }^{18}$ Although God's Crown has been known for its promising health benefits and widely used in the field of alternative medicine to treat various diseases, it has not been optimally applied in dentistry. ${ }^{19}$ The present study aimed to determine if God's Crown extract could reduce the bacterial density in periodontal disease caused by biofilms formed by $P$. gingivalis, A. Actinomycetemcomitans, and $T$. denticola, as well as multispecies biofilm, in vitro.

\section{MATERIALS AND METHODS}

This experimental laboratory in vitro research study aimed to investigate the inhibition property of God's Crown extract (Phaleria macrocarpa) against the biofilm density of $P$. gingivalis, A. actinomycetemcomitans, and $T$. denticola, using a biofilm assay method with a posttest only control design. 


\section{God's Crown Extraction}

The God's Crown extract was obtained from the Perkebunan Borobudur \& Extraction Center, Semarang, Indonesia. The extraction was performed by drying the God's Crown fruit, scaled with a scale (Kern \& Sohn, Balingen), and then sorted, cleaned, and smashed into small fragments. The fragments were soaked in $70 \%$ ethanol and evaporated, then dried, to obtain the extracts. ${ }^{11,12}$ The dried extracts were diluted with aquadest to create four different concentrations.

\section{Phytochemical Screening}

The God's Crown extracts were tested for the presence of flavonoids, triterpenoids, alkaloids, saponins, tannins, phenolics, and glycosides. The results are expressed as positive (+) for the presence and negative (-) for the absence of phytochemicals substances.

\section{Bacterial Cultures}

P. gingivalis ATCC 33277, A. actinomycetemcomitans ATCC 33384, and T. denticola ATCC 354045 were cultured in brain heart infusion (BHI) broth (Merck Millipore, Darmstadt), and then incubated for $48 \mathrm{~h}$ (JISICO incubator, Seoul) in an anaerobic environment. Turbidity was measured using a microplate reader (SAFAS Monaco, Monaco) with a wave length of 600 $\mathrm{nm}$; the sample was diluted by adding BHI broth until the bacterial concentration was $3 \times 10^{8} \mathrm{CFU} / \mathrm{mL}(\mathrm{OD} 600=$ $0,25) .20$

\section{Biofilm Assay}

For each of the three bacterial cultures, $200 \mathrm{ml}$ of $P$. gingivalis ATCC 33277, A. actinomycetemcomitans ATCC 33384, and T. denticola ATCC 354045, was inserted into 96-well microplates (Nest Biotechnology, Jiangsu) using a micropipette (Corning, New York) coated with artificial saliva and incubated for $48 \mathrm{~h}$ to form the biofilm. ${ }^{21,22}$ Then, different concentrations of God's Grown extract $(3.125 \%, 6.25 \%, 12.5 \%$, and $25 \%)$ were added to the bacterial cultures, which were then incubated for $1 \mathrm{~h}, 6 \mathrm{~h}$, and $24 \mathrm{~h}$. Moreover, the microplate was rinsed twice with phosphate buffer saline (PBS) (Biomatik, Cambridge) and dried. Then, $200 \mathrm{~mL}$ of $0.05 \%$ crystal violet solution was added to each well for $15 \mathrm{~min}$; rinsed with PBS. In the final step, $200 \mathrm{~mL}$ of 99\% ethanol was added to the cultures, and the biofilm density was measured using a microplate reader with a wavelength of $600 \mathrm{~nm}$.

The data were analyzed using Shapiro-Wilk's normality test. A comparative analysis was conducting using one-way ANOVA. The post-hoc test was used to measure the statistical significance. which was set at $\mathrm{p}<0.05$

\section{RESULTS}

The phytochemical test confirmed that this plant has some active components, such as alkaloids, saponins, tannins, phenolics, and flavonoids. The results are shown in Table 1. The data showed that God's Crown extract can reduce the biofilm density of $P$. gingivalis, $A$. actinomycetemcomitans, and $T$. denticola, as well as the density of the multispecies biofilm. It was found that the $25 \%$ concentration of God's Crown extract (incubated at 24h) was the most effective for reducing the biofilm density of $P$. gingivalis and T. denticola (Fig. 1 and 2). The $12.5 \%$ concentration of God's Crown extract (incubated for $6 \mathrm{~h}$ ) was the most effective for reducing the biofilm density of A. actinomycetem-comitans (Fig. 3). The concentration of God's Crown extract that was most effective for reducing the density of the multispecies biofilm was $25 \%$, incubated for $1 \mathrm{~h}$ (Fig. 4).

The statistical analysis data showed that the data was normally distributed ( $p>0.05)$. Comparative analysis of the data with one-way ANOVA showed that there was significant difference in all concentrations compared to negative control $(\mathrm{p}<0.05)$. A post-hoc test was used to determine the statistically significant difference. The results showed that there was a significant difference in the biofilm formation between all of the God's Crown extract concentrations $(3.125 \%, 6.25 \%, 12.5 \%$, and $25 \%)$ at all three incubations times $(1 \mathrm{~h}, 6 \mathrm{~h}$, and $24 \mathrm{~h})$ and the negative control (the biofilm without the fruit extract).

\section{DISCUSSION}

God's crown extract contains many bioactive compounds. Some of the compounds found in God's Crown extract, such as flavonoids, saponins, and tannins, have been proven to have antibacterial activity. ${ }^{16}$ Flavonoids (including kaempferol, myricetin, naringin, quercetin, and rutin) are the major bioactive components in God's crown fruit extract. ${ }^{11}$ Medicinal plants that contain flavonoids often possess high antimicrobial activity against pathogens. For example, pomegranate juice has been reported to be effective in eradicating periodontal pathogens consisted of $T$. denticola, $P$. gingivalis, and A. actinomycetemcomitans in vitro because pomegranate contains flavonoids in abundance. ${ }^{23}$

The antimicrobial activity against pathogenic microorganisms happens through several mechanisms, including disruption of cytoplasmic membrane function, inhibition of nucleic acid synthesis, and alteration of energy metabolism. ${ }^{24}$ Flavonoids in God's Crown extract can reduce the formation and attachment of pseudo- 
monas aeruginosa biofilm. Flavonoids can inhibit quorum sensing mechanism, a signal or communication system between bacterial cells in the biofilm that results in virulence. Some recent studies have shown that flavonoid can disrupt the interaction between acylhomoserine lactones (a Gram-negative bacteria signaling molecule), leading to the inhibition of quorum sensing. ${ }^{25}$ Other components like tannins can resist some bacterial virulence by inhibiting biofilm formation and neutralizing the bacterial toxin. ${ }^{26}$

Table 1. The phytochemical test results for God's Crown extract

\begin{tabular}{|c|c|c|c|}
\hline Extract & Test & Result & Method \\
\hline \multirow{9}{*}{$\begin{array}{l}\text { God's Crown } \\
\text { extract } \\
\text { (Phaleria } \\
\text { macrocarpa) }\end{array}$} & \multicolumn{2}{|c|}{ Phytochemical test : } & Qualitative \\
\hline & Alkaloids & + & \\
\hline & Saponins & + & \\
\hline & Tannins & + & \\
\hline & Phenolics & + & \\
\hline & Flavonoids & + & \\
\hline & Triterpenoids & - & \\
\hline & Steroids & - & \\
\hline & Glycosides & - & \\
\hline
\end{tabular}

The present study found that God's Crown extract effectively reduces multispecies biofilm density. Takasaki et al. reported that $P$. gingivalis has a competitive relationship with $A$. actinomycetemcomitans in biofilm..$^{27}$ Among the bacteria in sub-gingival plaque in a biofilm community, there are cooperative and competitive relationships between species when forming the biofilm. The formation of biofilm is initiated by the attachment of initial colonizers (early colonizers) to the tooth surface or surrounding tissue, continued with the bonding of late colonizing bacteria. Takasaki et al. also reported that $P$. gingivalis (a late colonizer) can release A. actinomycetemcomitans (an initial colonizer) that is already attached to the tooth surface, so there was less multispecies biofilm formation than mono-species biofilm formation. ${ }^{27}$

Study found that the flavonoids in God's Crown extract can inhibit the growth of other Gram-negative bacteria, such as Escherichia coli (E. coli), and Grampositive bacteria, such as Staphylococcus aureus ( $S$. aureus). The inhibition was more effective in $S$. aureus than in $E$. coli, because, as a type of Gram-negative bacteria, most of the cell membrane of $E$. coli consists of lipopolysaccharides and $2 \%-10 \%$ consists of peptidoglycans; in Gram-positive bacteria, 50\% of the cell membrane consists of peptidoglycans; the membrane does not contain any lipopolysaccharides. ${ }^{28}$ The flavonoids in God's Crown leaves or fruit make it more difficult for bacteria to penetrate lipopolysaccharides than peptidoglycans. Therefore, higher concentration of God's Crown extract is needed. ${ }^{29}$ The present study's findings agree with the results reported by Suryani et al. ${ }^{28}$ which is that the flavonoids in God's Crown extract can significantly reduce the density of the biofilm formed by $P$. gingivalis, A. actinomycetemcomitans, and $T$. denticola.

\section{Porphyromonas gingivalis Biofilm}

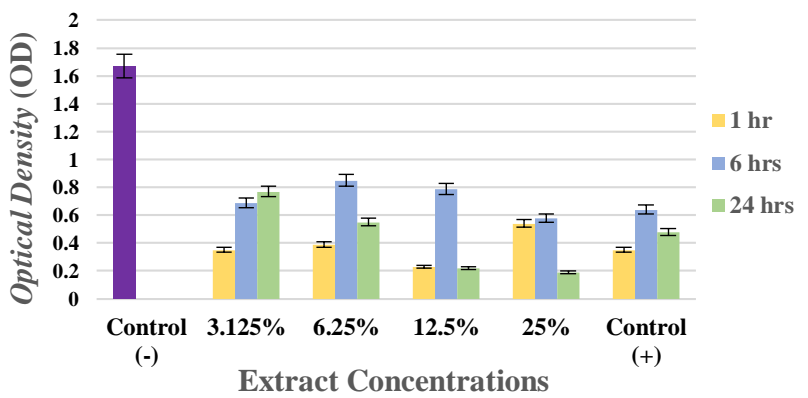

Figure 1. Reduction of $P$. gingivalis biofilm (OD) after probiotic treatment with God's Crown extract in different concentrations $(3.125 \%, 6.25 \%, 12.5 \%, 25 \%)$ after $1 \mathrm{~h}$, $6 \mathrm{~h}$, and $24 \mathrm{~h}$ of incubation period

\section{Treponema denticola Biofilm}

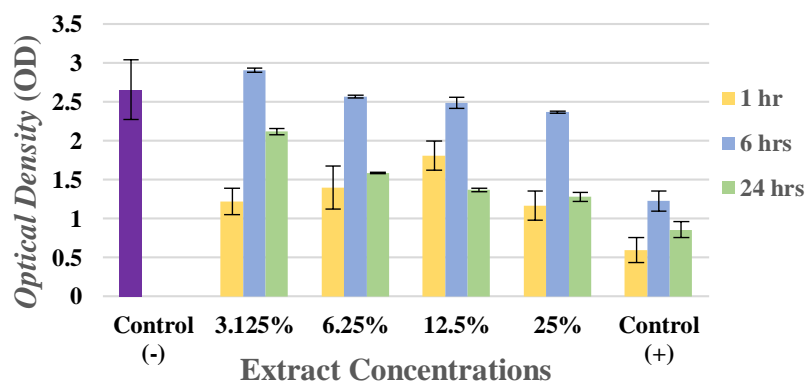

Figure 2. Reduction of $T$. denticola biofilm (OD) after probiotic treatment with God's Crown extract in different concentrations $(3.125 \%, 6.25 \%, 12.5 \%, 25 \%)$ after $1 \mathrm{~h}$, $6 \mathrm{~h}$, and $24 \mathrm{~h}$ of incubation period

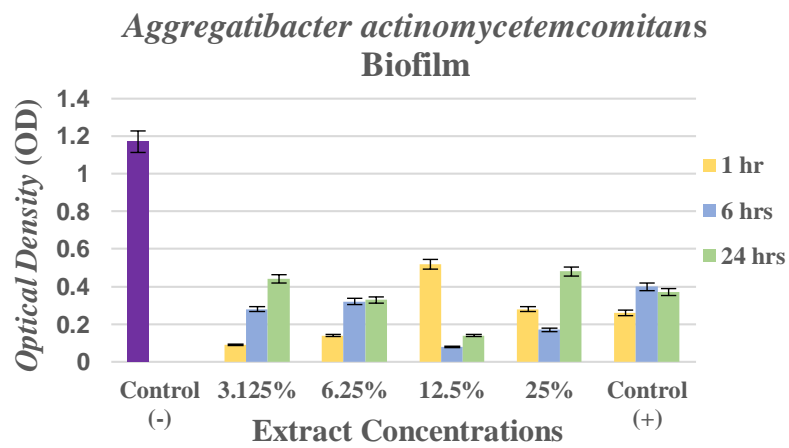

Figure 3. Reduction of A. actinomycetemcomintans biofilm (OD) after probiotic treatment with God's Crown extract in different concentrations $(3.125 \%, 6.25 \%$, $12.5 \%, 25 \%$ ) after $1 \mathrm{~h}, 6 \mathrm{~h}$, and $24 \mathrm{~h}$ of incubation period 


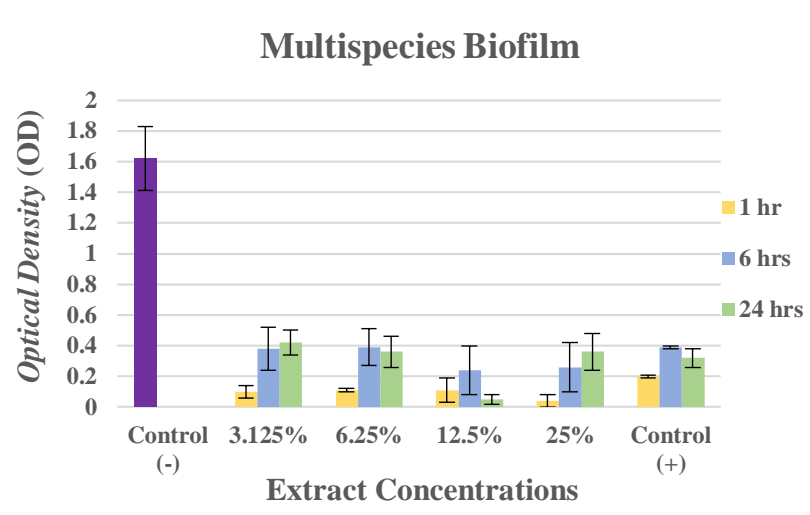

Figure 4. Reduction of multispecies biofilm (OD) after probiotic treatment with God's Crown extract in different concentrations $(3.125 \%, 6.25 \%, 12.5 \%, 25 \%)$ after $1 \mathrm{~h}$, $6 \mathrm{~h}$, and $24 \mathrm{~h}$ of incubation period

\section{CONCLUSION}

God's Crown extract can reduce the density of the biofilm formed by $P$. gingivalis, A. actinomycetemcomitans, $T$. denticola, and multispecies biofilms. The extract has the potential to become an alternative therapy for preventing periodontal disease. However, in vivo research is needed to perform a toxicity test to verify the safety of God's Crown extract for use as a long-term medicine.

\section{CONFLICT OF INTEREST}

The authors declare that they have noconflict of interest.

\section{REFERENCES}

1. Palombo EA. Traditional medicinal plant extracts and natural products with activity against oral bacteria: Potential application in the prevention and treatment of oral diseases. eCAM. 2011;8(1):1-11.

2. Situasi Kesehatan Gigi dan Mulut. Infodatin (Pusat Data dan Informasi Kementrian Kesehatan RI). 2014. Hal 1.

3. Bahekar AA, Singh S, Saha S, Molnar J, Arora R. The prevalence and incidence of coronary heart disease is significantly increased in periodontitis: A meta-analysis. Am Hear J. 2007;154(5):830-7.

4. Kim TS, Schenk A, Lungeanu D, Reitmeir P, Eickholz P. Nonsurgical and surgical periodontal therapy in single-rooted teeth. Clin Oral Investig. 2007;11(4):391-9.

5. Kothari S, Gnanaranjan G, Kothiyal P. Periodontal Chip: An Adjunct to Conventional Surgical Treatment. International Drug Research Technology. 2012.

6. Armitage GC. Comparison of the microbiological features of chronic and aggressive periodontitis.
Periodontology 2000. 2010;53(1):70-88.

7. Thomas JG, Nakaishi LA. Managing the complexity of a dynamic biofilm. Journal American Dental Association. 2006;137:10-15.

8. Hojo K, Nagaoka S, Ohshima T, Maeda N. Bacterial interactions in dental biofilm development. Journal Dental Research. 2011;88(11).

9. Dias DA, Urban S, Roessner U. A historical overview of natural products in drug discovery. Metabolites. 2012;2:303-336.

10. Manian R, Anusuya N, Siddhuraju P, Manian S. The antioxidant activity and free radical scavenging potential of two different solvent extracts of Camellia sinensis (L.) O. Kuntz, Ficus bengalensis L. and Ficus racemosa L. Food Chem. 2008;107(3):1000-7.

11. Hendra R, Ahmad S, Sukari A, Shukor MY, Oskoueian E. Flavonoid analyses and antimicrobial activity of various parts of Phaleria macrocarpa (Scheff.) Boerl fruit. Int J Mol Sci. 2011;12(6):342231.

12. Hendra R, Ahmad S, Oskoueian E, Sukari A, Shukor MY. Antioxidant, anti-inflammatory and cytotoxicity of Phaleria macrocarpa (Boerl.) Scheff fruit. BMC Complement Alternative Medicine [Internet]. 2011;11(1):110. Tersedia pada: http://www.biomedcentral.com/1472-6882/11/110.

13. Naharsari, Firman Wahyudi DA. Mahkota Dewa dan Manfaatnya. 2007. p. 8.

14. Lay MM, Karsani SA, Mohajer S, Abd Malek SN. Phytochemical constituents, nutritional values, phenolics, flavonols, flavonoids, antioxidant and cytotoxicity studies on Phaleria macrocarpa (Scheff.) Boerl fruits. BMC Complement Altern Med. 2014;14(1):152.

15. Altaf R, Asmawi MZ Bin, Dewa A, Sadikun A, Umar MI. Phytochemistry and medicinal properties of Phaleria macrocarpa (Scheff.) Boerl. extracts. Pharmacogn Rev. 2013;7(13):73-80.

16. Shamsudin H, Yunus B, Uddin S. Bioactive compounds and advanced processing technology: Phaleria macrocarpa (sheff.) Boerl, a review. J Chem Technol Biotechnol. 2015;90(6):981-91.

17. Liliany D, Widyarman AS, Erfan E, Sudiono J, Djamil MS. Enzymatic activity of bromelain isolated from pineapple (Ananas comosus) hump and its antibacterial effect on Enterococcus faecalis. Sci Dent J. 2018;2:39-50.

18. Widyarman AS, Widjaja SB, Idrus E. Strawberry extract's effects on Enterococcus faecalis and Porphyromonas gingivalis biofilms in vitro. Sci Dent J. 2017;1:1-5.

19. Susilawati, Matsjeh S, Pranowo HD, Anwar C. Two isophalerin compounds from ethyl acetate of leave and fruit of mahkota dewa (Phaleria macrocarpa (Scheff.) Boerl.) and its antibacterial activity. Indones J Chem. 2015;15(2):179-86. 
20. Periasamy, Saravanan, KP. Aggregatibacter antinomycetemcomitans Builds Mutualistic Biofilm Communities with Fusobacterium nucleatum and Veillonella Species in Saliva. Infection Immunology. 2009;77(9):3542-3551.

21. Shao H, Lamont R DD. Autoinducer 2 is Required for Biofilm Growth of Aggregatibacter actinomycetemcomitans. Infection Immunology. 2007;75(9):4211-4218

22. Novak E, Shao H, Daep C DD. Autoinducer-2 and QseC Control Biofilm Formation and in vivo Virulence of Aggregatibacter actinomycetemcomitans. Infection Immunology. 2010;78(7):2919-26.

23. Widyarman AS, Suhalim OP, Nandary D, Theodorea CF. Pomegranate juice inhibits periodontal paathogens biofilm in vitro. Sci Dent J. 2018;3:101108.

24. Xie Y, Yang W, Tang F, Chen X, Ren L. Antibacterial activities of flavonoids: structureactivity relationship and mechanism. Curr Med Chem. 2015;22(1):132-49.
25. Cushnie TPT, Lamb AJ. Recent advances in understanding the antibacterial properties of flavonoids. Int J Antimicrob Agents. 2011;38(2):99107.

26. Daglia M. Polyphenols as antimicrobial agents. Curr Opin Biotechnol. 2012;23(2):174-81.

27. Takasaki K, Fujise O, Miura M, Hamachi T, Maeda K. Porphyromonas gingivalis displays a competitive advantage over Aggregatibacter actinomycetemcomitans in co-cultured biofilm. J Periodontal Res. 2013;48(3):286-92.

28. Suryani L, Stepriyani S. Daya Antibakteri Infusa Daun Mahkota Dewa ( Phaleria macrocarpa) terhadap Staphylococcus aureus dan Eschericia coli The Antibacterial Activity of Mahkota Dewa leaf Infusion against Staphylococcus aureus and Eschericia coli. 2007;7(1):23-24.

29. Mutschler. Dinamika Obat. Mathilda, Widiarto AS, editor. Bandung: ITB; 1991;664-667 